\title{
PENERAPAN ALGORITMA GENETIKA UNTUK PENGIRIMAN BARANG PADA JASA PENGIRIMAN BARANG
}

\author{
Tubagus Riko Rivanthio, S.Kom. \\ Dosen Program Studi Manajemen Informatika \\ Politeknik LP3I Bandung \\ Email : riko rivanthio@yahoo.com
}

\begin{abstract}
Abstrak : Pada proses pengiriman barang diperlukan suatu perencanaan yang baik dan efisien. Perencanaan tersebut bertujuan untuk menentukan suatu jalur yang akan dilalui dalam mengirimkan barang, supaya terhindar dari pemborosan biaya operasional dalam mengirimkan barang. Algoritma Genetika merupakan salah satu algoritma yang dapat digunakan untuk mencari jalur pengiriman barang dengan waktu tempuh paling minimum.
\end{abstract}

Proses pencarian jalur tercepat menggunakan algoritma genetika tersebut dipengaruhi oleh beberapa parameter, yang teridiri dari nilai popsize, maksimum generasi, crossover, mutasi dan waktu berbobot dengan tiga periode.

Berdasarkan pengujian bahwa semakin besar nilai popsize, nilai maksimum generasi dan nilai crossover maka semakin baik waktu tempuh yang diperoleh. Sedangkan untuk nilai mutasi, akan menghasilkan waktu tempuh yang baik, jika nilai mutase tidak terlalu besar dan tidak terlalu kecil.

Kata Kunci : Algoritma Genetika, pengiriman barang

\section{Pendahuluan}

\subsection{Latar Belakang Masalah}

Dewasa ini usaha jasa pengiriman barang semakin menjamur, seiring dengan pesatnya perkembangan teknologi informasi, dimana pada saat ini transaksi jual beli bisa dilakukan melalui media online yaitu internet. Pada transaksi online ini, konsumen dapat memesan barang dari suatu toko online yang berasal dari kota yang berbeda dengan konsumen, kemudian toko online tersebut akan mengirimkan barang yang dipesan oleh konsumen melalui jasa pengiriman, sehingga jasa pengiriman barang sangatlah dibutuhkan oleh para pelaku transaksi online.

Semakin banyak para pelaku transaksi online bertransaksi maka semakin banyak permintaan pengiriman barang, dan semakin banyak permintaan pengiriman barang maka semakin banyak keuntungan yang akan diperoleh oleh perusahaan jasa pengiriman. Namun perusahaan jasa pengiriman harus memperhitungkan biaya operasional pengiriman barang tersebut, terlebih lagi biaya bahan bakar kendaraan saat ini cukup tinggi, sehingga diperlukan suatu perencanaan pengiriman dengan baik.

Salah satu faktor yang dapat memboroskan biaya operasional pengiriman barang adalah kemacetan lalu lintas yang digunakan untuk mengirimkan barang yang 
diakibatkan oleh padatnya pengguna jalan, sehingga berdampak pada pemborosan bahan bakar dan waktu dalam pengiriman barang. Biasanya padatnya pengguna jalan terjadi pada waktu-waktu tertentu, misalnya pada waktu pagi hari atau siang hari, karena hampir seluruh ativitas manusia dilakukan pada waktu/jam-jam tersebut. Kemacetan lalu lintas pada suatu jalan/jalur tidak sepenuhnya terjadi dalam satu hari penuh, akan tetapi kemungkinan biasanya kemacetan hanya akan terjadi pada waktu pagi atau pada jam-jam tertentu. Misalnya kota A ke kota B pada pagi hari akan sangat padat pengguna jalan sehingga menimbulkan kemacetan, sedangkan pada siang hari pengguna jalan akan sedikit berkurang dikarenakan hampir semua orang beraktifitas ditempat kerja masing-masing. Maka waktu tempuh dari kota A ke kota B pada waktu pagi hari akan berbeda dengan waktu tempuh pada siang hari, ataupun pada malam hari.

Solusi untuk menghindari kemacetan dalam pengiriman barang adalah diperlukan suatu perencanaan untuk mengambil keputusan dalam menentukan jalur dengan waktu tempuh yang minimum dan penentuan jam/waktu keberangkatan untuk mendistribusikan barang agar tehindar dari kemacetan pada jalur-jalur/ waktuwaktu tertentu sehingga dapat menghemat waktu dan biaya operasional.

Perencanaan pengambilan keputusan dalam menentukan jalur dengan waktu tempuh yang minimum dapat menggunakan teknik algortima genetika. Algoritma ini sering digunakan untuk mengatasai masalah Traveling Salesman. Algoritma Genetika adalah algoritma pencarian heuristik yang didasarkan atas mekanisme evolusi biologis. Pemanfaatan metode pencarian heuristik inilah yang dimanfaatkan dalam mencari jalur dengan waktu tempuh yang minimum.

\subsection{Identifikasi Masalah}

Berdasarkan latar belakang permasalahan diatas, maka dapat diidentifikasi masalah sebagai berikut:

1. Bagaimana mengetahui informasi jalur yang cepat, efektif dan efisien dalam pengiriman barang?

2. Bagaimana menentukan perencanaan pengambilan jalur pengiriman barang yang cepat, efektif dan efisien?

\subsection{Batasan Masalah}

1. Terdapat 3 (tiga) selang waktu/periode berbobot dinamik adalah sebagai berikut :
a) $07: 00-12: 00$.
b) $13: 00-18: 00$.
c) 19:00-06.00.

2. Pada aplikasi ini hanya terdapat satu gudang yang akan menjadi supplier dan semua kota akan dikunjungi satu kali dengan graf yang simetris.

3. Waktu tempuh jalur/sirkuit ditransformasikan kedalam bentuk satuan jam, misalnya waktu tempuh jalur sirkuit adalah 10 jam.

\section{Landasan Teori}

\subsection{Konsep Pengiriman Barang}


Menurut Mulyadi (2001:201), sistem pengiriman barang merupakan suatu kegiatan mengirim barang dikarenakan adanya penjualan barang dagang. Penjualan terdiri dari transaksi penjualan barang atau jasa, baik secara tunai atau kredit.

Secara umum pengirman barang merupakan mempersiapkan pengiriman fisik barang dari gudang ketempat tujuan yang disesuakan dengan dokumen pemesanan dan pengiriman serta dalam kondisi yang sesuai dengan persyaratan penanganan barangnya

\subsection{Algoritma Genetika}

Menurut Kusumadewi (2005) Algoritma Genetika adalah algoritma pencarian heuristik yang didasarkan atas mekanisme evolusi biologis. Keberagaman pada evolusi biologis adalah variasi dari kromosom antar individu organisme. Variasi kromosom ini akan mempengaruhi laju reproduksi dan tingkat kemajuan organisme untuk tetap hidup.

Pada dasarnya ada 4 kondisi yang sangat mempengaruhi proses evaluasi, yakni sebagai berikut :

a. Kemampuan organisme untuk menahan laju reproduksi.

b. Keberadaan populasi organisme yang bisa melakukan reproduksi.

c. Keberagaman organisme dalam suatu populasi.

d. Perbedaan kemampuan untuk survive.

Individu yang lebih kuat (fit) akan memiliki tingkat survival dan tingkat reproduksi yang lebih tinggi jika dibandingkan dengan individu yang kurang fit. Pada kurun waktu tertentu (sering dikenal dengan istilah generasi) populasi secara keseluruhan akan lebih banyak memuat organisme yang fit.

Algoritma genetika pertama kali dikembangkan oleh John Holland dari Universitas Michigan (1975). John Holland mengatakan bahwa setiap masalah yang berbentuk adaptasi (alami maupun buatan) dapat diformulasikan dalam terminologi genetika.

Dalam rangka memanfaatkan algoritma genetika, maka algoritma genetika telah banyak diaplikasikan untuk menyelesaikan masalah dan pemodelan dalam bidang teknologi, bisnis, dan entertainment, seperti :

1. Optimasi.

Algoritma genetika digunakan untuk optimasi numerik dan optimasi kombinatorial seperti travelling salesman problem (TSP), perancangan IC, job shop sceduling, optimasi suara dan video.

2. Pemrograman Otomatis.

Algoritma genetik digunakan untuk melakukan proses evolusi terhadap program komputer untuk merancang struktur komputasional, seperti cellular automata dan sorting networks.

3. Machine Learning. 
Algoritma genetik berhasil diaplikasikan untuk memprediksi struktur protein. Algoritma genetik juga berhasil dalam perancangan neural network (jaringan syaraf tiruan). Algotima genetik juga digunakan untuk mengendalikan robot.

4. Model Ekonomi.

Algoritma genetik digunakan untuk memodelkan sistem-sistem inovasi, memprediksi produksi dan lab perusahaan.

Algoritma genetika bekerja secara iteratif pada ruang pencarian yang tersusun dari semua kemungkinan solusi. Untaian solusi ini merupakan analogi sebuah kromosom, dimana setiap kromosom memiliki sebuah nilai fungsi obyektif yang bersesuaian dengan parameter masalah yang disebut nilai fitnes (fitness value). Apabila sebuah kromosom dikatakan unggul berarti memiliki nilai fitnes yang tinggi (untuk masalah maksimasi) atau nilai fitness yang rendah (untuk masalah minimasi). Nilai fitnes menunjukkan kromosom mana yang memiliki potensi terbaik untuk diturunkan pada generasi berikutnya. Satu tahapan iterasi pada algoritma genetika disebut generasi, dan selama langkah ini struktur dalam populasi saat itu akan dievaluasi untuk menentukan populasi pada generasi berikutnya. Algoritma genetika yang sederhana minimal menggunakan tiga operator genetika, yaitu reproduksi,kawin silang (crossover), dan mutasi.

Kerangka algoritma genetika sederhana adalah sebagai berikut :

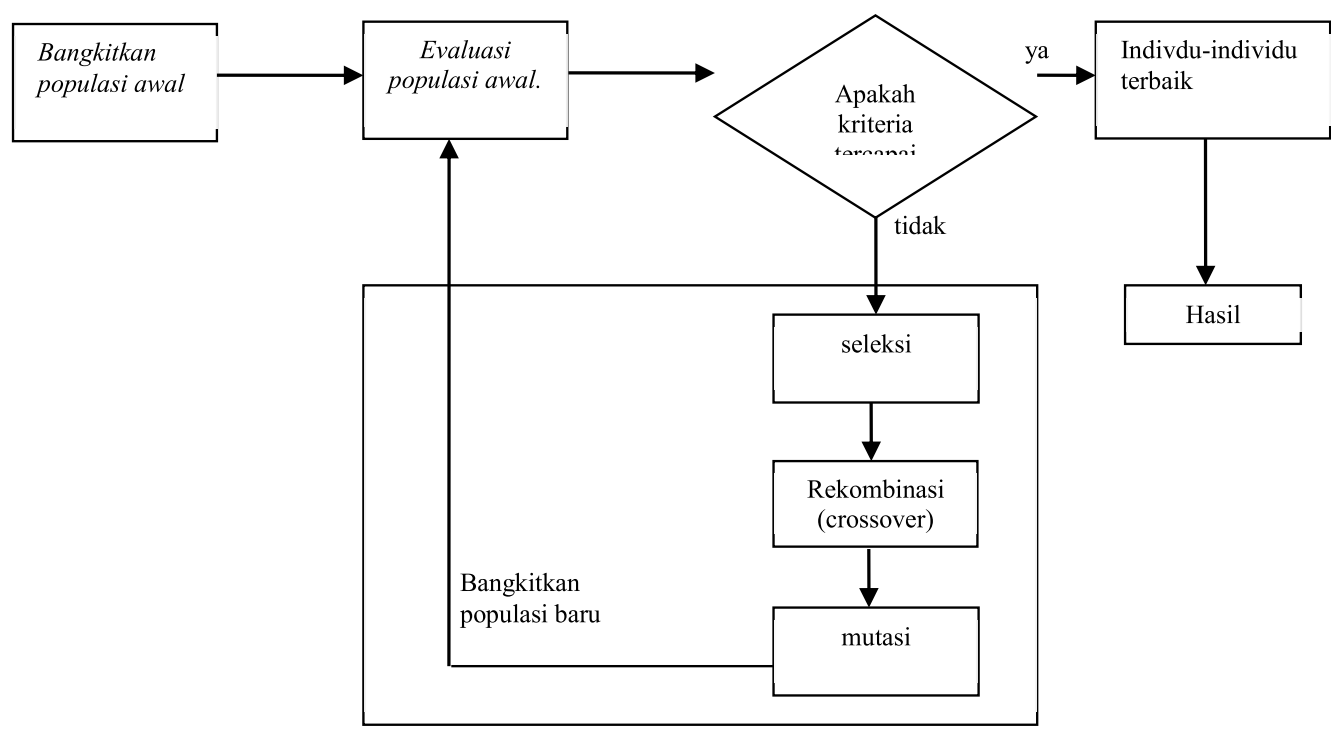

Gambar. II.4. Diagram Alir Algoritma Genetika sederhana

\subsubsection{Struktur Umum Algoritma Genetika}

1. Representasi Kromosom

Untuk dapat menggunakan algoritma genetika terlebih harus dilakukan pengkodean parameter dari masalah yang akan diselesaikan ke dalam bentuk representasi kromosom. Representasi dapat menggunakan kode biner, floating point, array, dan sebagainya.

2. Inisialisai Populasi 
Pada tahap ini, ditentukan terlebih dahulu nilai awal dari sejumlah untaian yang membentuk populasi. Penentuan populasi awal ini dapat dipilih secara heuristik atau secara acak.

3. Seleksi

Seleksi berguna untuk mencapai nilai target yang ditentukan dari optimasi parameter yang ingin dicapai. Setiap kromosom dari populasi akan dievaluasi berdasarkan fungsi objektif yang bekerja dengan mengiolah parameter-parameter yang telah dikodekan dari setiap kromosom

4. Kawin silang

Pada genetic algorihtm, kawin silang merekombinasi material genetika yang dimiliki kromosom dua induk untuk menghasilkan dua keturunan dengan probabilitas tertentu, yang disebut probabilitas kawin silang (Pc).

5. Mutasi

Mutasi diperlukan untuk mengembalikan informasi bit yang hilang akibat proses yang dilakukan operator lain, dan diterapkan dengan probabilitas tertentu $(P \mathrm{~m})$.

\subsubsection{Parameter kendali algoritma genetika}

Hal-hal yang harus dipertimbangkan dalam menggunakan algoritma genetika adalah:

1. Representasi gen dari solusi

2. Ukuran solusi yang dipertahankan pada setiap generasi

3. Penyeleksian dan jumlah induk

4. Penurunan dan jumlah keturunan yang dihasilkan dari induk, termasuk kemungkinan mutasi

5. Evaluasi solusi yang diseleksi untuk generasi berikutnya

6. Kondisi berhenti (stopping condition) algoritma

\section{Analis Dan Perancangan}

\subsection{Analisis Sistem}

\subsubsection{Deskripsi Sistem}

Pada dasarnya sistem untuk pendistribusian barang secara dinamis ini ditentukan berdasarkan selang waktu/periode perubahan yang telah ditentukan oleh waktu/periode pagi, siang, dan malam. Sehingga besaran waktu yang dibutuhkan dari kota A ke kota B pada waktu/periode pagi akan berbeda dengan besaran waktu yang dibutuhkan pada siang, ataupun malam.

\subsubsection{Analisis Algoritma Genetika}

Untuk memperoleh besaran waktu yang minimum/tercepat dalam algoritma genetika, memiliki 4 tahapan untuk memperoleh waktu minimum, tahapan tersebut adalah :

1. Membuat tabel matrik untuk selang waktu periode, yaitu: 

a. Jika jamberangkat $>7$ dan $<=12$ maka selang waktu/periode adalah pagi.
b. Jika jamberangkat $>1$ dan $<=18$ maka selang waktu/periode adalah siang.
c. Jika jamberangkat $>19$ dan $<=24$ maka selang waktu/periode adalah malam.
d. Jika jamberangkat $>1$ dan $<=6$ maka selang waktu/periode adalah malam

2. Masukan parameter awal yaitu : banyaklokasi, jamberangkat, lokasiawal berangkat, popsize, maksimum generasi, peluang crossover ( $p c)$, peluang mutasi(pm).

3. Inisialisasi awal dengan cara membangkitkan ruang solusi secara acak sebanyak popsize(populasi).

4. Evaluasi setiap setiap solusi yang ada dalam populasi dengan menghitung nilai fitness dan waktu tempuh dari setiap jalur/lintasan pada populasi awal..

5. Melakukan proses seleksi dengan metode roulette wheel yaitu menghitung nilai fitness kumulatif dan fitness relatif pada setiap kromosom yang dihasilkan pada populasi awal, dan nilai fitness yang tinggi akan direproduksi.

Algoritma seleksi roulette wheel adalah sebagai berikut:

a. Hitung total fitness $(\mathrm{F})$ : TotFitness $=\sum \mathrm{Fk}$;

b. Hitung fitness relative tiap individu : ${ }_{\mathrm{K}}=\mathrm{Fk} /$ TotFitness.

c. Fitness kumulatif: : ${ }_{k}={ }_{k-1}+{ }_{K}$

d. Memilih induk yang akan menjadi kandidat untuk dicrossover dengan cara:

- bangkitkan bilangan random $r$.

- jika ${ }^{\mathrm{q}_{\mathrm{k}}} £ \mathrm{r}$ dan ${ }_{\mathrm{k}+1}>\mathrm{r}$, maka pilih kromosom ke $(\mathrm{K}+1)$ sebagai kandidat induk

e. Melakukan kawin silang/crossover, dimana crossover adalah operator genetik yang menggabungkan dua kromosom (parent) untuk menghasilkan kromosom baru (offspring). Ide dari crossover adalah membuat kromosom baru (anak) lebih baik dari kedua orangtuanya. Jika diambil karakterisktik yang tebaik dari setiap orang tua. Crossover terjadi selama evolusi berdasarkan kemungkinan yang telah ditetapkan.

Prosedur crossover

a. Bangkitkan bilangan random/ acak $\mathrm{r}$ sebanyak populasi

b. Jika (kromosom ke-i $=r(i))<p c$ maka kromosom ke-i akan di crossover.

c. Jika jumlah kromosom ganjil maka salah satu kromosom akan dibuang

d. Silangkan kromosom-1 dengan kromosom-2, dengan cara bangkitkan dua bilangan random antara 1 sampai banyak kota, kemudian silangkan anggota-anggota kromosom yang berada pada area bilangan random tadi.

Prosedur Mutasi

a. Bangkitkan bilangan random/ acak r.sebanyak populasi * panjang kromosom/banyak kota.

b. Jika $($ kromosom-i $=r(i))<p m$ maka kromosom ke-i akan dimutasi.

c. Tukarkan dua anggota pada kromosom ke-i dengan cara membangkitkan dua bilangan bilangan random 
d. Populasi akhir setelah dimutasikan akan menjadi populasi awal pada generasi berikutnya sampai maksimum generasi tercapai.

e. Memilih waktu yang tercepat setiap kromosom/jalur yang dihasilkan.

\subsubsection{Analisis Kebutuhan Fungsional}

3.1.3.1 Diagram Konteks

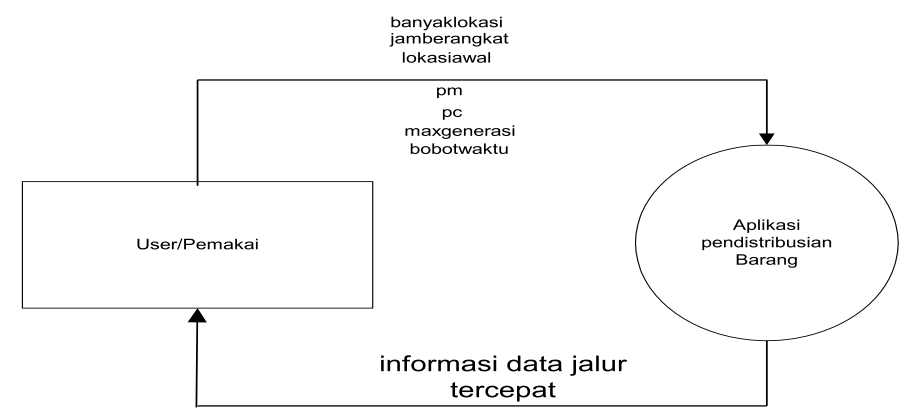

gambar. III.1 Diagram Konteks

\subsubsection{Data Flow Diagram level 1}

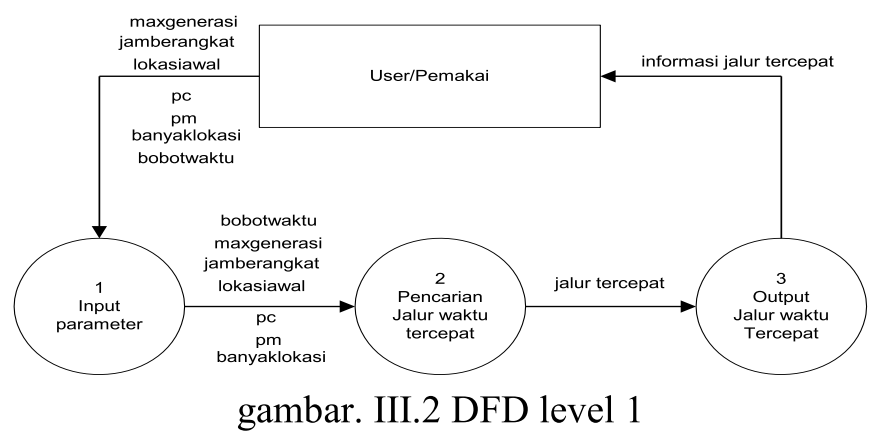

\subsubsection{Data Flow Diagram level 2 Proses pencarian jalur waktu tercepat}

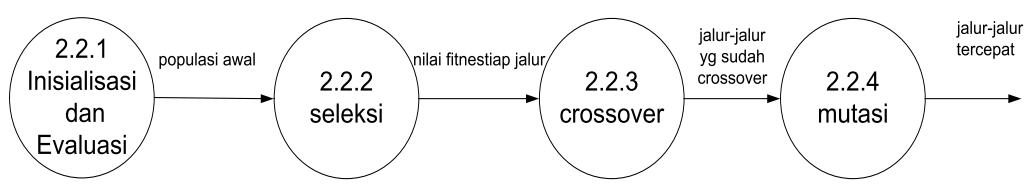

gambar. III.3 DFD level 2 Proses Algoritma Genetika

\section{Pengujian}

\subsection{Batasan Pengujian}

Pada aplikasi ini mempunyai beberapa batasan Pengujian, adapun batasan pengujian adalah sebagai berikut:

1. Input Data
a. Banyak kota
: $\quad$ antara 2 sampai 100. 

b. Kota asal
: antara 1 sampai banyak kota.
c. Jam berangkat
: antara 1 sampai 24 , dan satuan waktunya
d. Popsize yaitu adalah jam.
e. Maksimum generasi : antara 1 sampai 500.
f. Probabilitas crossover : antara 1 sampai 100, dengan bentuk formatnya adalah persen.
g. Probabilitas mutasi : antara 1 sampai 100 , dengan bentuk formatnya adalah persen.

2. Terdapat tiga selang waktu/periode yang tetap yaitu pagi $(07: 00-12: 00)$, siang (13:00 - 18:00), malam (19:00 - 06:00),

3. Bobot waktu pada tiga selang waktu/periode bersifat statis/tetap, sehingga bobot waktu tidak dapat dirubah, dan inputan bobot diperoleh secara random dengan ketentuan untuk table pagi bilangan randomnya antara 3 sampai 7 , pada tabel siang bilangan randomnya antara 2 sampai 6 , dan untuk tabel malam bilangan randomnya antara 1 sampai 5 .

\begin{tabular}{|c|c|c|c|c|c|c|c|c|c|c|c|c|c|c|c|c|c|c|c|c|c|c|c|c|c|c|c|c|}
\hline \multicolumn{10}{|c|}{ Waktu Pagi (pukul 07.00- 12.00) } & \multicolumn{9}{|c|}{ Waktu Siang (pukul 13.00-18.00) } & \multicolumn{10}{|c|}{ Waktu Malam( pukul 19.00-06.00) } \\
\hline Kot:1 & 2 & & & 4 & 5 & 6 & 7 & 18 & $9 \hat{\imath}$ & Kot: & & 2 & & 4 & 5 & 6 & 7 & 18 人 & Kot: & & & 3 & 4 & 5 & 16 & & & {$[€ \wedge$} \\
\hline 100 & 3 & & & 5 & 6 & 7 & 6 & 5 & 4 & 1 & 0 & 2 & 3 & 4 & 5 & 6 & 5 & 4 & 1 & 0 & & 2 & 3 & 4 & 5 & 4 & 3 & 2 国 \\
\hline 2 & 0 & 3 & & 4 & 5 & 6 & 7 & 6 & 5 & 2 & 2 & 0 & 2 & 3 & 4 & 5 & 6 & 5 & 2 & & & 1 & 2 & 3 & 4 & 5 & 4 & \\
\hline 3 & 3 & 0 & & 3 & 4 & 5 & 6 & 7 & 6 & 3 & 3 & 2 & 0 & 2 & 3 & 4 & 5 & 6 & 3 & 2 & & 0 & 1 & 2 & 3 & 4 & 5 & 4 \\
\hline 4 & 4 & 3 & & 0 & 3 & 4 & 5 & 6 & 7 & 4 & 4 & 3 & 2 & 0 & 2 & 3 & 4 & 5 & 4 & 3 & 2 & 1 & 0 & 1 & 2 & 3 & 4 & 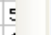 \\
\hline 5 & 5 & & & 3 & 0 & 3 & 4 & 5 & 6 & 5 & 5 & 4 & 3 & 2 & 0 & 2 & 3 & 4 & 5 & 4 & 3 & 2 & 1 & 0 & 1 & 2 & 3 & 4 \\
\hline 6 & 6 & 5 & & 4 & 3 & 0 & 3 & 4 & 5 & 6 & 6 & 5 & 4 & 3 & 2 & 0 & 2 & 3 & 6 & 5 & 4 & 3 & 2 & 1 & 0 & 1 & 2 & 8 \\
\hline 7 & 7 & & & 5 & 4 & 3 & 0 & 3 & 4 & 7 & 5 & 6 & 5 & 4 & 3 & 2 & 0 & 2 & 7 & 4 & & 4 & 3 & 2 & 1 & 0 & 1 & $\bar{z}$ \\
\hline 8 & 6 & & & 6 & 5 & 4 & 3 & 0 & 3 & 8 & 4 & 5 & 6 & 5 & 4 & 3 & 2 & 0 & 8 & & & 5 & 4 & 3 & 2 & 1 & 0 & 1 \\
\hline 9 & 5 & & & 7 & 6 & 5 & 4 & 3 & 0 & 9 & 3 & 4 & 5 & 6 & 5 & 4 & 3 & 2 & & & & 4 & 5 & 4 & 3 & 2 & & \\
\hline 10 & 4 & & & 6 & 7 & 6 & 5 & 4 & 32 & 10 & 2 & 3 & 4 & 5 & 6 & 5 & 4 & 3 & 10 & & & 3 & 4 & 5 & 4 & 3 & 2 & $1 v$ \\
\hline$<\ldots$ & & & & & & & & & $>$ & $<$ & & & & & & & & $>$ & $<$ & & & & & & & & ? & (5) \\
\hline
\end{tabular}

gambar. IV.1 Bobot waktu antar kota dengan tiga periode waktu

\subsection{Pengujian Algoritma Genetika Dengan Berbeda Parameter}

Pengujian algoritma genetika dengan berbeda parameter dilakukan sebanyak 10 kali pengujian, dengan salah satu parameternya berbeda dan parameter lainnya tetap.

1. Pengujian Pertama : Popsize

Setting parameter :
a. banyak kota $: 10$.
b. Kota asal $\quad: 1$.
c. Jam berangkat $\quad: 7$.
d. Pop Size $\quad:\{100,200,300,400,500,600,700,800,900,1000)$.
e. Maksimum Generasi $: 100$.
f. Probabilitas Crossover (pc) : 75 .
g. Probabilitas Mutasi (pm) : 25 .
Maka grafik pengujian yang diperoleh adalah sebagai berikut : 


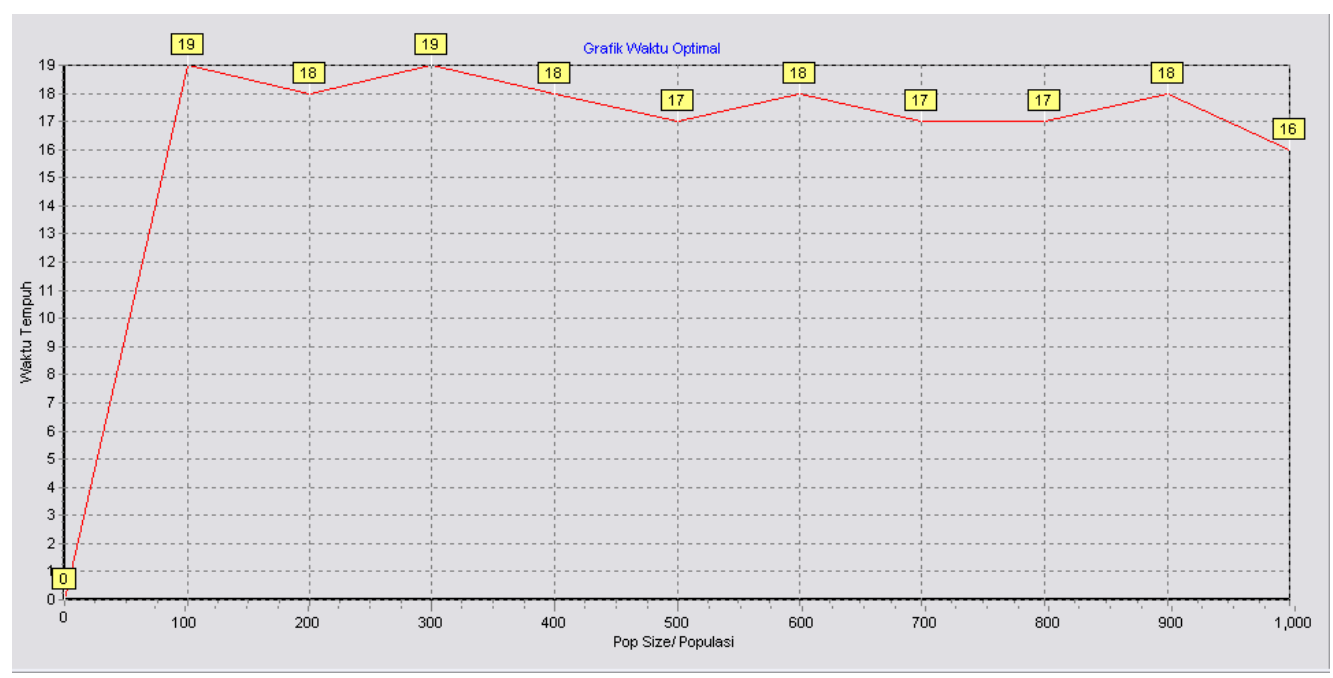

Gambar IV.2. Grafik pengujian popsize yang berbeda.

Hasil pengujian didapatkan populasi dari 10 kali pengujian dengan berbeda popsize maka dapat disimpulkan semakin besar popsize kemungkinan waktu tempuh akan semakin baik, sehingga diperoleh waktu tempuh maksimal dari hasil pengujian adalah waktu tempuh 16 jam yaitu : pada pengujian ke -10 , dengan popsize : 1000. Dan popsize 1000 akan menjadi parameter input popsize untuk pengujian selanjutnya.

2. Pengujian Kedua : Maksimum Generasi

Setting parameter :

a. banyak kota $: 10$.

b. Kota asal $\quad: 1$.

c. Jam berangkat $\quad: 7$.

d. Pop Size $\quad: 1000$.

e. Maksimum Generasi $\quad$ : $\{50,100,150,200,250,300,350,400,450,500\}$

f. Probabilitas Crossover (pc) : 75 .

g. Probabilitas Mutasi (pm) : 25 .

Maka grafik pengujian yang diperoleh adalah sebagai berikut :

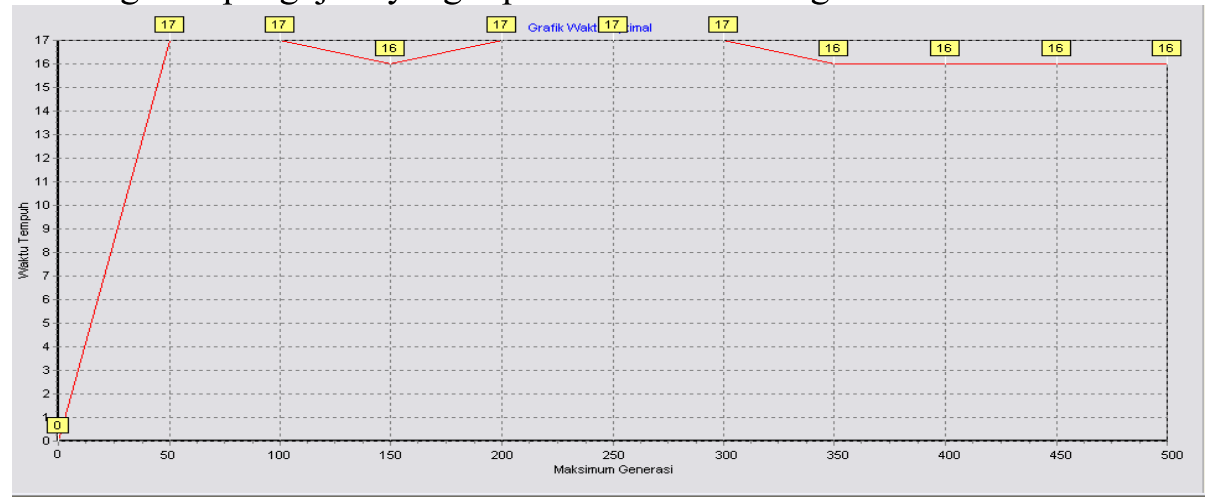

Gambar IV.3. Grafik pengujian generasi maksimum yang berbeda.

Hasil pengujian didapatkan maksimum generasi dari 10 kali pengujian dapat diperoleh kesimpulan bahwa semakin banyak generasi maka waktu tempuh akan semakin baik, sehingga diperoleh waktu tempuh maksimal dari hasil pengujian 
adalah waktu tempuh 16 jam, yaitu : pada pengujian ke-3, dengan maksimum generasi : 150. Dan maksimum generasi 150 akan menjadi parameter input maksimum generasi untuk pengujian selanjutnya.

3. Pengujian Ketiga : Probabilitas Crossover (pc)

Setting parameter :

a. banyak kota $\quad: 10$

b. Kota asal $: 1$.

c. Jam berangkat $\quad: 7$.

d. Pop Size $: 1000$.

e. Maksimum Generasi $\quad: 150$.

f. Probabilitas Crossover (pc) $\quad:\{10,20,30,40,50,60,70,80,90,100\}$.

g. Probabilitas Mutasi (pm) : 25 .

Maka grafik pengujian yang diperoleh adalah sebagai berikut :

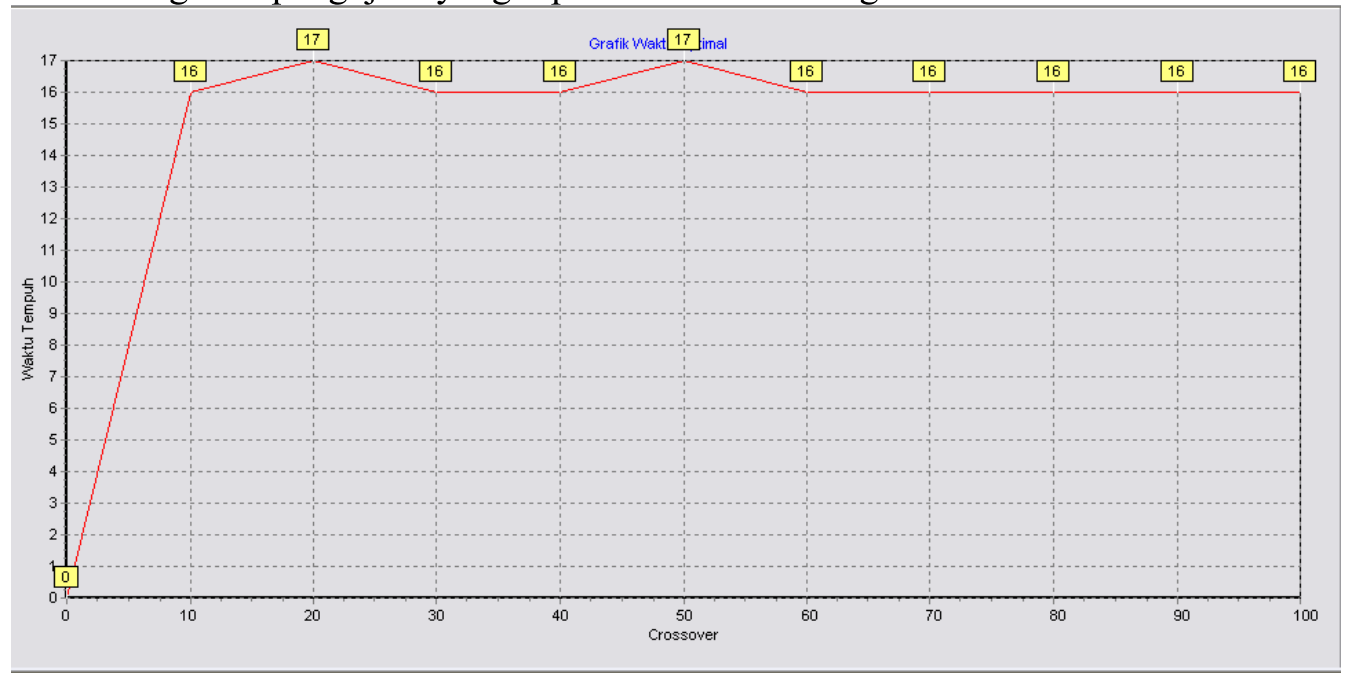

Gambar IV.4. Grafik pengujian probabilitas crossover yang berbeda.

Hasil pengujian didapatkan pobabilitas crossover dari 10 kali pengujian dapat diperoleh kesimpulan bahwa semakin besar nilai crossover kemungkinan waktu tempuh yang diperoleh akan semakin baik, sehingga nilai maksimal dari hasil pengujian adalah waktu tempuh 16 jam, yaitu : pada pengujian ke-6, dengan probabilitas crossover : 60 . Dan probabilitas crossover 60 akan menjadi parameter input probabilitas crossover untuk pengujian selanjutnya.

4. Pengujian keempat: Probabilitas Mutasi(pm)

Setting parameter :
a. banyak kota
$: 10$
b. Kota asal
$: 1$.
c. Jam berangkat
$: 7$.
d. Pop Size
$: 1000$.
e. Maksimum Generasi $\quad: 150$.
f. Probabilitas Crossover (pc) : 60 .
g. Probabilitas Mutasi (pm) $:\{10,20,30,40,50,60,70,80,90,100\}$
Maka grafik pengujian yang diperoleh adalah sebagai berikut : 


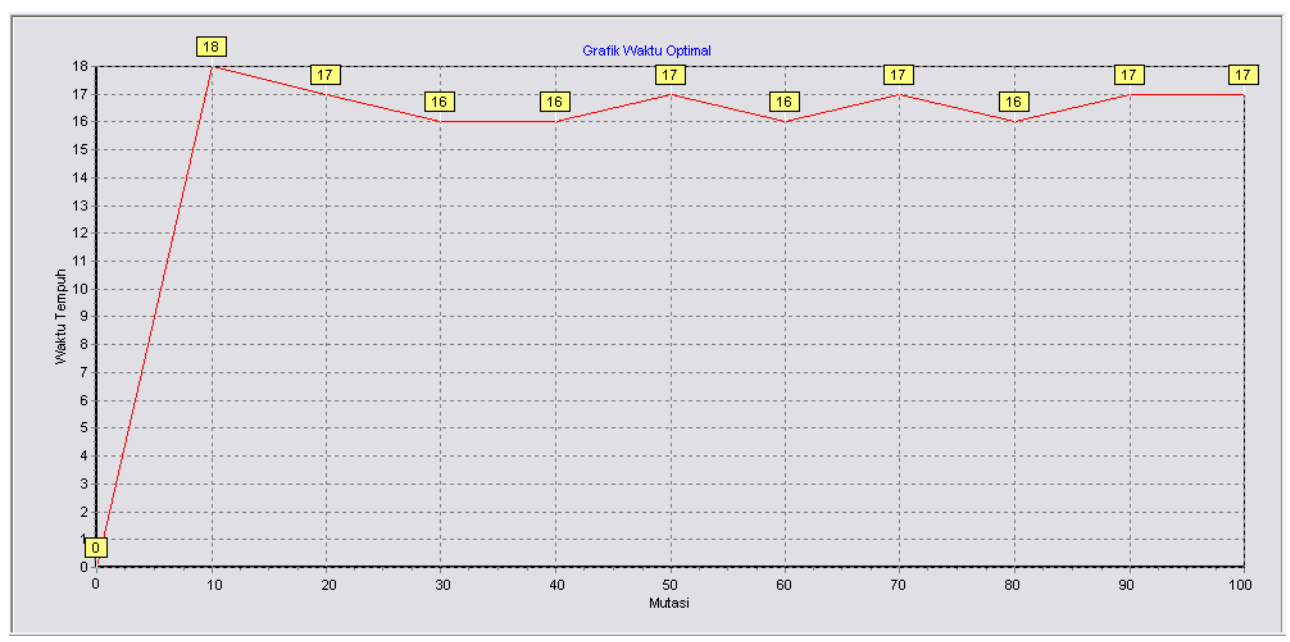

Gambar IV.5. Grafik pengujian probabilitas mutasi yang berbeda.

Hasil pengujian didapatkan pobabilitas mutasi dari 10 kali pengujian dapat diperoleh kesimpulan bahwa semakin besar nilai mutasi maka waktu tempuh yang diperoleh tidak menghasilkan waktu tempuh yang baik, begitu juga untuk nilai probabilitas mutasi yang semakin kecil tidak dapat memperoleh waktu tempuh yang baik, sehingga terdapat suatu nilai tertentu untuk mutasi yang nilainya tidak terlalu kecil dan tidak terlalu besar, maka dari hasil pengujian didapatkan hasil waktu tempuh maksimal adalah $16 \mathrm{Jam}$ yaitu : pada pengujian ke-3, waktu tempuh 16 Jam, dengan probabilitas mutasi : 30 .

\section{Kesimpulan Dan Saran}

\subsection{Kesimpulan}

Dari uraian pembahasan pada bab-bab sebelumnya maka dapat diperoleh kesimpulan bahwa:

1. Algoritma genetika dapat memberikan solusi dalam pencarian jalur terpendek pada proses pengiriman barang.

2. Proses pencarian jalur terpendek tersebut dipengaruhi oleh beberapa parameter seperti popsize, maksimum generasi, crossover, dan mutasi serta jam berangkat

3. Hasil pengujian menunjukkan bahwa semakin besar nilai popsize, nilai maksimum generasi dan nilai crossover maka semakin baik waktu tempuh yang diperoleh. Sedangkan untuk nilai mutasi, akan menghasilkan waktu tempuh yang baik, jika nilai mutase tidak terlalu besar dan tidak terlalu kecil.

\subsection{Saran}

Adapun saran-saran yang akan dikembangkan lagi adalah :

1. Pengembangan perangkat lunak pencarian waktu tercepat pada pendistribusian barang dengan graf yang asimetris.

2. Membandingkan dengan algoritma-algoritma yang lainnya atau membandingkan antara pencarian jalur pendistribusian barang dengan acuan waktu tempuh dan dengan acuan jarak tempuh.. 


\section{Daftar Pustaka}

[1] Kusumadewi, Sri dan Purnomo, Hari, Penyelesaian Masalah Optimasi dengan Teknik-teknik heuristik, Graha Ilmu, 2005.

[2] Mulyadi, Sistem Akuntansi, Jakarta: Salemba Empat, 2001. 